\title{
Agrobacterium-Mediated Transformation of Amaranthus cruentus L. Epicotils
}

\author{
Ragida M. Taipova**, \\ Khalit G. Musinin and Bulat R. Kulueva,b \\ ${ }^{a}$ Bashkir State University \\ Ufa, Russian Federation \\ ${ }^{b}$ Institute of Biochemistry and Genetics - Subdivision of \\ the Ufa Federal Research Centre of the RAS \\ Ufa, Russian Federation
}

Received 02.03.2018, received in revised form 13.04.2018, accepted 27.04.2018, published online 08.04.2019

\begin{abstract}
Red amaranth Amaranthus cruentus L. is a valuable fodder and grain crop. To generate new varieties of this plant, genetic transformation methods can be used, but for A. cruentus such methods remain undeveloped. The present study describes the results of our research in Agrobacteriummediated transformation of epicotyl segments of A. cruentus variety "Bagryanyi" by the ARGOSLIKE transgene of Arabidopsis thaliana controlled by the $35 \mathrm{~S}$ promoter in the binary vector pCambia 1301 with a selective hygromycin B resistance gene. For shoot regeneration from epicotyl segments after Agrobacterium-mediated transformation, Murashige-Skoog (MS) medium containing $13 \mu \mathrm{M}$ 6-benzylaminopurine and $1 \mu \mathrm{M}$ 1-naphthylacetic acid was used. For the selection of transgenic shoots, $10 \mathrm{mg} / \mathrm{L}$ of hygromycin B was added to the MS medium. Rooting of shoots was performed on selective MS medium supplemented with $2 \mu \mathrm{M} 3$-indoleacetic acid. Three transgenic amaranth plants with the genetic engineering structure $35 S:: A R G O S$-LIKE were generated. The efficiency of Agrobacteriummediated transformation of $A$. cruentus was $4 \%$. The amaranth plants transgenicity was confirmed by the PCR analysis for the presence of marker and target genes. Two transgenic plants were acclimatized to soil and open air conditions.
\end{abstract}

Keywords: Amaranthus cruentus, red amaranth, in vitro, shoots regeneration, Agrobacteriummediated transformation, transgenic plants, ARGOS-LIKE.

Citation: Taipova R.M., Musin K.G., Kuluev B.R. Agrobacterium-mediated transformation of Amaranthus cruentus L. epicotils. J. Sib. Fed. Univ. Biol., 2020, 13(2), 179-187. DOI: 10.17516/1997-1389-0292

(C) Siberian Federal University. All rights reserved

This work is licensed under a Creative Commons Attribution-NonCommercial 4.0 International License (CC BY-NC 4.0).

* Corresponding author E-mail address: taipova.ragida@yandex.ru 


\title{
Агробактериальная трансформация \\ эксплантов эпикотилей амаранта багряного
}

\section{Amaranthus cruentus L.}

\author{
Р.М. Таипова ${ }^{\mathrm{a}}$ Х.Г. Мусин ${ }^{\mathrm{a}, \boldsymbol{6}}$, Б.Р. Кулуев ${ }^{\mathrm{a}, \bar{\sigma}}$ \\ ${ }^{a}$ Башкирский государственный университет \\ Российская Федерачия, Уфа \\ ${ }^{6}$ Институт биохимии и генетики - \\ обособленное структурное подразделение \\ Уфимского федерального исследовательского центра РАН \\ Российская Федерация, Уфа
}

\begin{abstract}
Аннотация. Амарант багряный Amaranthus cruentus L. является ценной кормовой и зерновой культурой. Для получения новых сортов этого растения могут быть использованы методы генетической трансформации, однако для A. cruentus такие технологии остаются неразработанными. Данная статья посвящена описанию результатов наших работ по агробактериальной трансформации сегментов эпикотилей A. cruentus сорта «Багряный» трансгеном ARGOS-LIKE Arabidopsis thaliana L., находящимся под контролем 35S промотора в бинарном векторе pCambia 1301 с селективным геном устойчивости к гигромицину В. Для регенерации побегов из сегментов эпикотилей после агробактериальной трансформации использовали среду Мурасиге-Скуга, содержащую 13 мкМ 6-бензиламинопурина и 1 мкМ 1-нафтилуксусной кислоты. Для селекции трансгенных побегов амаранта в среду добавляли 10 мг/л гигромицина В. Укоренение полученных в ходе работы регенерантов проводили на селективной среде МС с добавлением 2 мкМ 3-индолилуксусной кислоты. В ходе проведенной работы были получены 3 трансгенных растения амаранта багряного, несущие генноинженерную конструкцию $35 S:: A R G O S$-LIKE. Трансгенность полученных растений амаранта была подтверждена путем ПЦР-анализа на наличие маркерных и целевого генов. Процент эффективности агробактериальной трансформации A. cruentus при использованном нами методе составил 4 \%. Два трансгенных растения удалось акклиматизировать к условиям почвы и открытого воздуха.
\end{abstract}

Ключевые слова: Amaranthus cruentus, амарант багряный, in vitro, регенерация побегов, агробактериальная трансформация, трансгенные растения, ARGOS-LIKE.

Цитирование: Таипова, Р.М. Агробактериальная трансформация эксплантов эпикотилей амаранта багряного Amaranthus cruentus L. / Р.М. Таипова, Х.Г. Мусин, Б.Р. Кулуев // Журн. Сиб. федер. ун-та. Биология, 2020. 13(2). С. 179187. DOI: $10.17516 / 1997-1389-0292$ 


\section{Введение}

Амарант является растением, применяемым в качестве овощной, кормовой, зерновой, лекарственной и декоративной культур. Высокая питательная ценность, обусловленная повышенным содержанием белка, сбалансированного по аминокислотному составу, количеству витаминов и минеральных солей, делает привлекательным использование амаранта в кулинарии, медицине и сельском хозяйстве (Магомедов, Чиркова, 2015).

Селекционные работы по выведению новых сортов амаранта в России ведутся довольно интенсивно. Получено большое количество отечественных сортов этой культуры с улучшенными ростовыми характеристиками, с повышенной урожайностью и другими хозяйственно ценными признаками (Жужукин, Шор, 2010). Амарант продолжает набирать популярность и может стать одной из важных культур, выращиваемых отечественными сельхозпроизводителями. Одним из препятствий для широкого распространения амаранта является его относительно низкая холодоустойчивость ввиду южного происхождения культуры. Суровые климатические условия нашей страны могут оказывать негативное воздействие, прежде всего, на урожайность амаранта. Для увеличения продуктивности и стрессоустойчивости амаранта могут быть использованы не только методы селекции, но и современные генно-инженерные технологии (Таипова, Кулуев, 2015; Kuluev et al., 2017).

В настоящее время методы трансформации амаранта остаются мало разработанными. В литературе имеются данные лишь о нескольких исследованиях по созданию трансгенных растений амаранта (Jofre-Garfias et al., 1997; Pal et al., 2013; Munusamy et al., 2013; Murugan, Sathishkumar, 2016), однако они не относятся к широко распространенному культурному виду амаранта багряного
Amaranthus cruentus L. В свою очередь ранее нами была испытана технология трансформации сорного вида амаранта запрокинутого Amaranthus retroflexus L. (щирица) методом погружения цветков (Kuluev et al., 2017). Однако эффективность трансформации амаранта запрокинутого методом погружения цветков оказалась очень низкой (не более 1,4 \%). Аналогичные эксперименты были проведены и на примере $A$. cruentus, однако методом floral dip нам не удалось получить ни одного трансгенного растения этого вида амаранта. В связи с этим остается актуальным вопрос разработки новых подходов для получения трансгенных растений этой культуры через использование методов регенерации побегов из эксплантов в условиях in vitro.

Продуктивность растений может быть повышена за счет влияния на рост органов. В основе контроля роста органов растений лежат два основных механизма, а именно регуляция клеточного деления и рост клеток растяжением (Gonzalez et al., 2012). Важную роль в координации процессов клеточного деления и растяжения играют белки семейства ARGOS (Feng et al., 2011; Кулуев, Сафиуллина, 2015). У Arabidopsis thaliana обнаружено и изучено четыре гена, кодирующие белки данной группы: $A R G O S, A R G O S-L I K E(A R L), O S R 1$ и OSR2 (Hu et al., 2003; Hu et al., 2006; Feng et al., 2011; Qin et al., 2014). Ген ARGOS-LIKE (ARL) A. thaliana кодирует трансмембранный белок, предположительно участвующий в передаче и трансдукции сигналов от фитогормонов к транскрипционным факторам. Сверхэкспрессия генов семейства $A R G O S$ способствует увеличению размеров надземных органов за счет положительного влияния на рост клеток растяжением (Hu et al., 2006), а также приводит к повышению стрессоустойчивости за счет негативного влияния на этиленовый сигналинг (Shi et al., 2015). Ранее нами были по- 
лучены трансгенные растения табака, рапса и амаранта запрокинутого, сверхэкспрессирующие ген $A R L$ (Kuluev et al., 2013; Михайлова, Кулуев, 2015; Kuluev et al., 2017), некоторые линии которых характеризовались увеличением размеров листьев и стебля по сравнению с контролем. Исходя из полученных ранее данных, генно-инженерная конструкция $35 S:: A R L$ была отобрана для трансформации хозяйственно-ценных растений.

Целью представленной работы была разработка метода агробактериальной трансформации культурного вида амаранта багряного A. cruentus с использованием генно-инженерной конструкции $35 S:: A R L$. Для этого была поставлена задача - получить трансгенные растения амаранта багряного посредством агробактериальной трансформации при культивировании эксплантов эпикотилей на селективных средах, содержащих гигромицин В.

\section{Материалы и методы}

В работе использовали генно-инженерную конструкцию $35 S:: A R L$, содержащую целевой ген ARGOS-LIKE из A. thaliana (Kuluev et al., 2013). Для опытов по агробактериальной трансформации растений амаранта использовали семена A. cruentus сорта «Багряный» (Агросервер, Россия), которые перед проращиванием стерилизовали 70 \%-ным этиловым спиртом в течение минуты и $20 \%$-ным раствором отбеливателя «Белизна» (ООО «Башбытпром», Стерлитамак, Россия; представляет собой $15 \%$-ный раствор гипохлорита натрия) в течение 8 минут, после чего семена тщательно промывали стерильной дистиллированной водой 5-6 раз. После этапа стерилизации семена амаранта рассевали на среду, содержащую половинную концентрацию солей среды Мурасиге-Скуга (МС) (Murashige, Skoog, 1962), витамины среды Гамборга (Gamborg et al., 1968) и 30 г/л саха- розы. Семена проращивали при температуре $27 \pm 1^{\circ} \mathrm{C}$ и интенсивности света 35 мкмоль $/ \mathrm{M}^{2} \cdot \mathrm{c}$. Для инокуляции эксплантов амаранта использовали культуру клеток штамма A. tumefaciens AGL, несущую генно-инженерную конструкцию $35 S:: A R L$ (Kuluev et al., 2013), которую культивировали в 15 мл жидкой среды LB, содержащей рифампицин и канамицин, на орбитальном шейкере при температуре $28{ }^{\circ} \mathrm{C}$ и скорости вращения 180 об/мин. Наращивание агробактерий продолжали до достижения оптической плотности, соответствующей концентрации $2-3 \times 10^{8}$ клеток/мл (обычно около 1 суток). Полученную суспензию агробактерий центрифугировали при 3500 об/мин в течение 10 минут, надосадочную жидкость сливали, а осадок ресуспендировали в эквивалентном объеме жидкой среды МС.

Из семидневных проростков в стерильных условиях вырезали сегменты семядольных листьев, гипокотилей и эпикотилей (экспланты) и культивировали в течение 6 суток на регенерационной среде МС, содержащей 13 мкМ 6-бензиламинопурина (БАП) и 1 мкМ 1-нафтилуксусной кислоты (НУК). Затем сегменты, предварительно подвергнутые поранению, погружали в бактериальную суспензию на 10 минут, после чего немного подсушивали стерильной фильтровальной бумагой и переносили на такую же регенерационную среду для сокультивации с агробактериями. В рамках всей работы было использовано 45 семядольных, 60 гипокотильных и 70 эпикотильных эксплантов.

Совместное культивирование эксплантов с агробактериями проводили в течение 2 суток, по истечении которых их промывали раствором антибиотика цефотаксима (300 мг/л) и переносили на селективную среду МС с теми же регуляторами роста (БАП и НУК) с аналогичными концентрациями и антибиотиками 

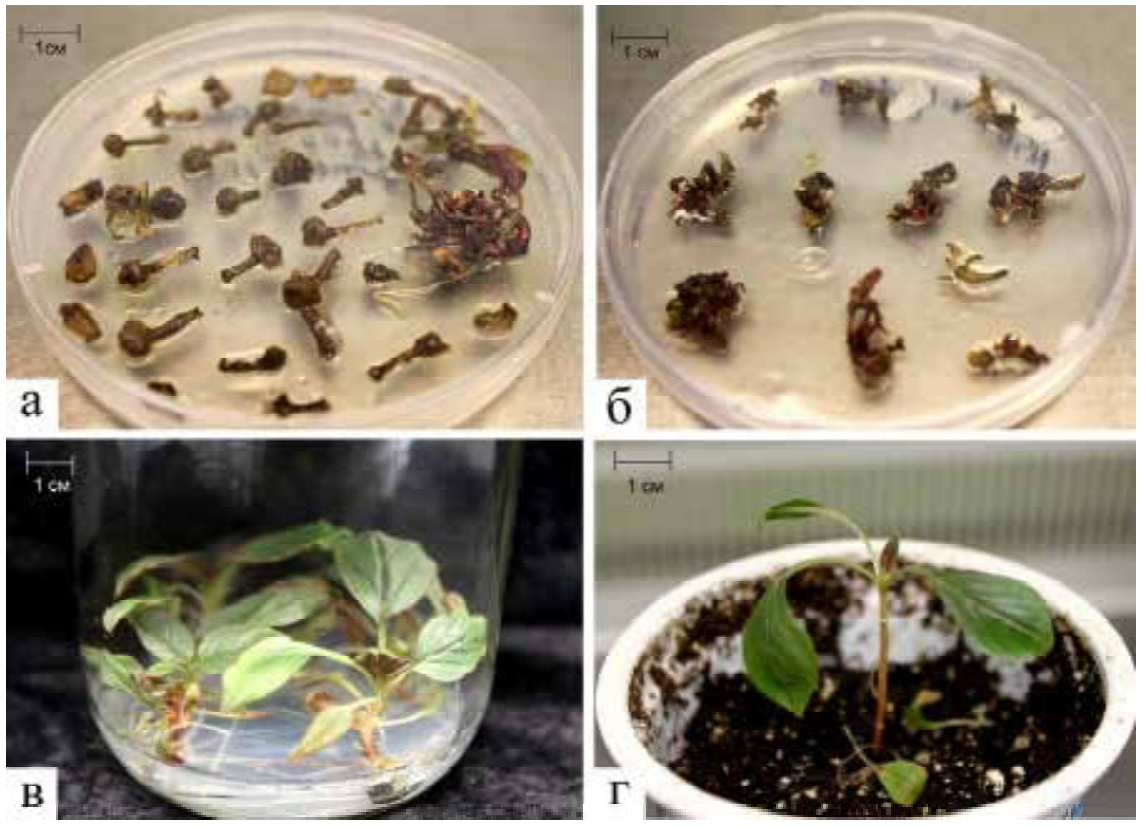

Рис. 1. Опыты по агробактериальной трансформации A. cruentus: a - образование каллуса на сегментах гипокотилей и регенерация побегов на сегментах эпикотилей на среде МС, содержащей 6-бензиламинопурин (БАП) и нафтилуксусную кислоту (НУК); б - регенерация побегов из сегментов эпикотилей после агробактериальной трансформации на селективной среде МС с БАП и НУК; в укоренение на среде МС с индолилуксусной кислотой; г-акклиматизация амаранта к условиям почвы

Fig. 1. Agrobacterium-mediated transformation of A. cruentus: a - the formation of callus on the hypocotyl segments and regeneration of the shoots on segments of epicotyls on MS medium with 6-benzylaminopurine (BAP) and naphthylacetic acid (NAA); 6 - regeneration of shoots from epicotyl segments after Agrobacterium transformation on selective MS medium with BAP and NAA; B - rooting of shoots on MS medium with indoleacetic acid; $\Gamma-$ acclimatization of amaranth to the soil conditions

цефотаксимом - 300 мг/л и гигромицином В (Gold Biotechnology, США) - 10 мг/л. Экспланты, на которых на селективной среде начинали регенерировать побеги, были пересажены на среду МС с 2 мкМ БАП и гигромицином В (10 мг/л) (рис. 1). Укоренение полученных в ходе работы регенерантов проводили на среде МС с добавлением 2 мкМ 3-индолилуксусной кислоты (ИУК) и гигромицина В в концентрации 10 мг/л. Укоренившиеся растения были акклиматизированы к условиям почвы и открытого воздуха. Для этого переносили амаранты в вегетационные сосуды объемом 450 мл, заполненные увлажненным универсальным грунтом Terra vita (Россия). Сверху растения накрывали прозрачными пласти- ковыми сосудами и выращивали в условиях отсутствия дополнительного освещения при комнатной температуре. Через неделю прозрачные пластиковые сосуды убирали и переносили растения в обычные условия световой комнаты (при температуре $27 \pm 1{ }^{\circ} \mathrm{C}$ и интенсивности света 35 мкмоль/ $\left.\mathbf{M}^{2} \cdot \mathrm{c}\right)$.

Из укоренившихся на селективной среде и акклиматизированных к условиям почвы растений амаранта выделяли ДНК методом солевой экстракции (Aljanabi, Martinez, 1997) и полученные образцы подвергали ПЦР-анализу на присутствие целевого гена $A R L$ и маркерных генов $\beta$-глюкуронидазы $(G U S)$ и гигромицинфосфотрансферазы (HPT). Для амплификации гена $A R L$ использовали праймеры 
5'-TCTACAAAACGACATCATAAACAT-3' и ACATAAAagtgGaAgAagAagAAA. Для ПЦР-анализа гена $G U S$ использовали праймеры 5'-TGTGGAATTGATCAGCGTTGGTG-3' и 5'-AAGCCGACAGCAGCAGTTTCATC-3' (размер ампликона 989 п.н., опт. температура отжига $\left.-59{ }^{\circ} \mathrm{C}\right)$. Для идентификации гена $H P T$ использовали праймеры 5'-GCTTCTGCGGGCGATTTGTG-3' и 5'-AGCTGCGCCGATGGTTTCTAC-3' (размер ампликона 786 п.н., опт. температура отжига $\left.-60{ }^{\circ} \mathrm{C}\right)$. Для исключения возможной контаминации агробактериями анализируемых трансгенных растений дополнительно проводили ПЦР-анализ на наличие хромосомного гена rpoA A. tumefaciens (AF111855.1), при этом использовали праймеры 5'-TTCTGTTGTCTTCTCTGCGTGGTG-3' и 5'-CGATTCTTCTTCTGCTTCCTTCTG-3' (размер ампликона 587 п.н., опт. температура отжига $\left.-59{ }^{\circ} \mathrm{C}\right)$. Электрофоретический анализ проводили в $1 \%$-ном агарозном геле в приборах модели Sub-Cell GT WIDE MINI («Bio-Rad Laboratories», CШA).

\section{Результаты и обсуждение}

Для данной работы по агробактериальной трансформации амаранта преимущественно были использованы эпикотильные экспланты из проростков A. cruentus, выращенных из стерильных семян. Выбор эпикотилей в качестве основных эксплантов объясняется тем, что наши опыты показали отсутствие регенерации побегов из гипокотильных сегментов и семядолей при использовании БАП и НУК (рис. 1a). На гипокотилях и семядольных эксплантах образовывался лишь каллус, но регенерации побегов не происходило. Поэтому при дальнейшей агробактериальной трансформации использовались сегменты эпикотилей (70 эксплантов).
За время предварительного культивирования эксплантов эпикотилей в течение 6 дней на регенерационной среде с добавлением БАП и НУК происходило увеличение размеров исходных эксплантов, видимо, благодаря наличию в среде ответственных за нормализацию процессов роста регуляторов.

Эпикотильные экспланты подвергали агробактериальной трансформации, несущей генно-инженерную конструкцию $35 S:: A R L$, предварительно поранив их иглой. Такой дополнительный этап работы был проведен для повышения частоты попадания бактерий в клетки амаранта. В ходе работы из эпикотильных эксплантов на селективной среде было получено 18 побегов (рис. 1б). Укоренение полученных побегов производили также на среде МС, содержащей 2 мкМ ИУК. В ходе работы укоренились 14 побегов (рис. 18). Далее все укоренившиеся побеги были использованы для оптимизации методов акклиматизации растений к условиям почвы и открытого воздуха (рис. 12). Из 14 укоренившихся регенератов 11 удалось акклиматизировать к условиям почвы.

Трансгенность полученных в ходе работы растений амаранта была определена методом ПЦР-анализа на наличие маркерных и целевого генов (рис. 2). ПЦР-анализ показал, что нами были получены 3 потенциальных трансгенных растения вида A. cruentus, несущих генно-инженерную конструкцию $35 S:: A R L$. Методом ПЦР было показано наличие в этих 3 растениях как целевого гена $A R L$, так и генов $H P T$ и GUS. Процент эффективности агробактериальной трансформации A. cruentus при использованном нами методе составил $4 \%$, то есть всего 4 \% обработанных агробактериями эксплантов эпикотилей дали трансгенные растения. Использованная для данной работы по трансформации сегментов эпикотилей генно-инженерная конструкция 


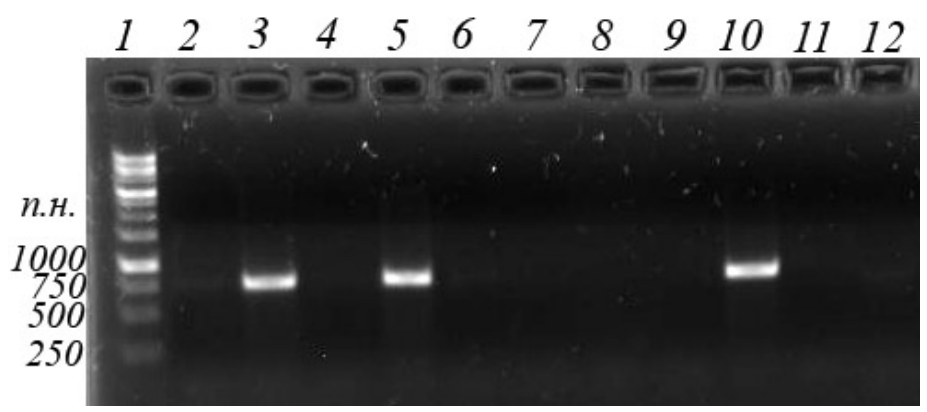

Рис. 2. Электрофореграмма результатов ПЦР-анализа A. cruentus на наличие гена гигромицинфосфотрансферазы (HPT). 1 - маркер молекулярного веса $1 \mathrm{~kb}$ (Евроген, Россия), 2-12 акклиматизированные растения амаранта. ПЦР-положительными оказались растения под номерами 2 , 4 и 9 (дорожки 3, 5 и 10 соответственно). Размер ампликона - 786 п.н.

Fig. 2. Electrophoretogram of the results of $A$. cruentus PCR analysis for the presence of hygromycin phosphotransferase gene (HPT). 1 - 1kb DNA Ladder (Evrogen, Russia), 2-12 - acclimatized amaranth plants. PCR-positive plants are 2, 4 and 9 (tracks 3, 5 and 10, respectively). The size of the amplicon is $786 \mathrm{bp}$.

содержит маркерный ген гигромицинфосфотрансферазы (HPT), продукт которого ответственен за устойчивость растений к антибиотику гигромицину. Предполагалось, что трансгенными должны быть побеги, сохранившие жизнеспособность и укоренившиеся на селективной среде с содержанием гигромицина, однако многие регенеранты оказались нетрансгенными. Возможно, для оптимизации селекции трансгенных побегов амаранта необходимо увеличение концентрации селективного антибиотика гигромицина в среде МС, использованной после сокультивирования эксплантов эпикотилей с агробактериями.

ПЦР-анализ на наличие гена $\operatorname{rpoA}$ A. tumefaciens показал его отсутствие во всех образцах ДНК анализируемых амарантов. Эти данные свидетельствуют об отсутствии агробактериальной контаминации в регенерантах амаранта, что в свою очередь доказывает трансгенность трех полученных нами растений. У двух трансгенных растений удалось получить семена, однако они оказались невсхожими. Мы полагаем, что невсхожесть семян связана не с генетической трансфор- мацией, а с условиями выращивания амаранта. В предыдущих работах с амарантом A. cruentus нам так же не удавалось получить всхожие семена этого растения при выращивании в лабораторных условиях. Однако те же растения давали полноценные семена при выращивании на открытом грунте. Вероятнее всего это связано с недостатком интенсивности света, так как амарант относится к светолюбивым растениям.

Ранее уже была показана эффективность использования эксплантов эпикотилей амаранта Amaranthus tricolor при агробактериальной трансформации (Pal et al., 2013). При этом авторы использовали бинарный вектор, несущий ген неомицинфосфотрансферазы. Новизна нашей работы заключается в том, что мы впервые показали возможность агробактериальной трансформации вида A. cruentus, при этом впервые для амаранта был использован бинарный вектор, несущий ген гигромицинфосфотрансферазы. Исходя из этих данных, можно предполагать, что использование сегментов эпикотилей при агробактериальной трансформации может оказаться эффективным для многих видов амаранта. При этом 
могут быть использованы бинарные векторы с генами устойчивости как к канамицину, так и гигромицину.

\section{Заключение}

Нами впервые проведена агробактериальная трансформация амаранта A. cruentus и оптимизирован протокол создания трансгенных растений этого вида амаранта с использованием гигромицина в качестве селективного агента. Наиболее оптимальным для агробактериальной трансформации A. cruentus является использование сегментов эпикотилей.

\section{Благодарности / Acknowledgements}

Исследования были проведены в рамках государственных заданий № АААА-A16-116020350028-4 и № АААА-А19-119021190011-0 с использованием оборудования РЦКП «Агидель» и УНУ «КОДИНК».

The research was carried out within the framework of state assignment № AAAA-A16-116020350028-4 and № AAAA-A19-119021190011-0 using the equipment of RCCU «Agidel» and USI «KODINK»

\section{Список литературы / References}

Жужукин В.И., Шор М.Ф. (2010) Изменчивость содержания питательных веществ при интродукции амаранта в Нижнем Поволжье. Кормопроизводство, 11: 28-31 [Zhuzhukin V.I., Shor M.F. (2010) Changeability of nutrients content during the process of amaranth introduction in Lower Volga region. Fodder Production [Kormoproizvodstvo], 11: 28-31 (in Russian)]

Кулуев Б.Р., Сафиуллина М.Г. (2015) Регуляция роста клеток растяжением в растениях. Успехи современной биологии, 135(2): 148-163 [Kuluev B.R., Safiullina M.G. (2015) Regulation of cell expansion in plants. Advances in Modern Biology [Uspekhi sovremennoj biologii], 135(2): 148-163 (in Russian)]

Магомедов И.М., Чиркова Т.В. (2015) Амарант - прошлое, настоящее и будущее. Усnехи современного естествознания, 1-7: 1108-1113 [Magomedov I.M., Chirkova T.V. (2015) Amaranth-past, present and future. Advances in Current Natural Sciences [Uspekhi sovremennogo estestvoznaniya], 1-7: 1108-1113 (in Russian)]

Михайлова Е.В., Кулуев Б.Р. (2015) Создание трансгенного рапса (Brassica napus L.) с конститутивной экспрессией гена ARGOS-LIKE Arabidopsis thaliana методом погружения цветков. Биотехнология, 5: 49-58 [Mikhaylova E.V., Kuluev B.R. (2015) Construction of transgenic rape (Brassica napus L.) overexpressing ARGOS-LIKE gene from Arabidopsis thaliana using the floral dip method. Biotechnology in Russia, 5: 49-58 (in Russian)]

Таипова Р.М., Кулуев Б.Р. (2015) Амарант: особенности культуры, применение, перспективы возделывания в России и создания трансгенных отечественных сортов. Биомика, 7(4): 284-299 [Taipova R.M., Kuluev B.R. (2015) Amaranth: features of culture, prospects of cultivation in Russia and generation of transgenic Russian varieties. Biomics [Biomika], 7(4): 284-299 (in Russian)]

Aljanabi S.M., Martinez I. (1997) Universal and rapid salt-extraction of high quality genomic DNA for PCR-based techniques. Nucleic Acids Research, 25(22): 4692- 4693

Feng G., Qin Z., Yan J., Zhang X., Hu Y. (2011) Arabidopsis ORGAN SIZE RELATED1 regulates organ growth and final organ size in orchestration with ARGOS and ARL. New Phytologist, 191(3): 635-646 
Gamborg O.L., Miller R.A., Ojima K. (1968) Nutrient requirements of suspension cultures of soybean root cells. Experimental Cell Research, 50(1): 151-158

Gonzalez N., Vanhaeren H., Inze D. (2012) Leaf size control: complex coordination of cell division and expansion. Trends in Plant Sciences, 17(6): 332-340

Hu Y., Poh H.M., Chua N.H. (2006) The Arabidopsis ARGOS-LIKE gene regulates cell expansion during organ growth. The Plant Journal, 47(1): 1-9

Hu Y., Xie Q., Chua N.H. (2003) The Arabidopsis auxin-inducible gene ARGOS controls lateral organ size. The Plant Cell, 15(9): 1951-1961

Jofre-Garfias A.E., Villegas-Sepúlveda N., Cabrera-Ponce J.L., Adame-Alvarez R.M., Herrera-Estrella L., Simpson J. (1997) Agrobacterium-mediated transformation of Amaranthus hypochondriacus: light- and tissue-specific expression of a pea chlorophyll a/b-binding protein promoter. Plant Cell Reports, 16(12): 847-852

Kuluev B.R., Knyazev A.V., Safiullina M.G., Chemeris A.V. (2013) Effect of constitutive expression of ARGOS-LIKE gene on sizes of cells and organs of transgenic tobacco plants. Russian Journal of Genetics, 49(5): 503-510

Kuluev B.R., Mikhaylova E.V., Taipova R.M., Chemeris A.V. (2017) Changes in phenotype of transgenic amaranth Amaranthus retroflexus L., overexpressing ARGOS-LIKE gene. Russian Journal of Genetics, 53(1): 67-75

Munusamy U., Abdullah S.N.A., Aziz M.A., Khazaai H. (2013) Female reproductive system of Amaranthus as the target for Agrobacterium-mediated transformation. Advances in Bioscience and Biotechnology, 4(2): 188-192

Murashige T., Skoog F. (1962) A revised medium for rapid growth and bio assays with tobacco tissue cultures. Physiologia Plantarum, 15(3): 473-497

Murugan S.B., Sathishkumar R. (2016) Establishment of high frequency callus induction and genetic transformation in neglected leafy vegetable Amaranthus trisis. Austin Journal of Biotechnology \& Bioengineering, 3(1): 1058

Pal A., Swain S.S., Das A.B., Mukherjee A.K., Chand P.K. (2013) Stable germ line transformation of a leafy vegetable crop amaranth (Amaranthus tricolor L.) mediated by Agrobacterium tumefaciens. In Vitro Cellular \& Developmental Biology - Plant, 49(2): 114-128

Qin Z., Zhang X., Zhang X., Feng G., Hu Y. (2014) The Arabidopsis ORGAN SIZE RELATED 2 is involved in regulation of cell expansion during organ growth. BMC Plant Biology, 14: 349

Shi J., Habben J.E., Archibald R.L., Drummond B.J., Chamberlin M.A., Williams R.W., Lafitte H.R., Weers B.P. (2015) Overexpression of ARGOS genes modifies plant sensitivity to ethylene, leading to improved drought tolerance in both Arabidopsis and Maize. Plant Physiology, 169(1): 266-282 